\title{
Antecedents of Brand Image: A Case of a Developing Country
}

\author{
Wasib B Latif ${ }^{1}$, Md. Aminul Islam ${ }^{1}$, Idris Bin Mohd Noor ${ }^{1}$, Syahira Bt Saaban ${ }^{1}$ \& A.B.M Abdul Halim² \\ ${ }^{1}$ School of Business Innovation and Technopreneurship, Universiti Malaysia Perlis, Kangar, Perlis, Malaysia \\ ${ }^{2}$ Department of Marketing, Govt. Titumir College, Dhaka, Bangladesh \\ Correspondence: Wasib B Latif, School of Business Innovation and Technopreneurship, Universiti Malaysia \\ Perlis, 01000, Kangar, Perlis, Malaysia. Tel: 60-16-632-2775. E-mail: wasibibaru@gmail.com; \\ wasibibaru@yahoo.com
}

Received: March 17, 2013 Accepted: April 24, 2014 Online Published: September 29, 2014

doi:10.5539/ass.v10n19p1 URL: http://dx.doi.org/10.5539/ass.v10n19p1

\begin{abstract}
The antecedents of brand image are defined as the differential effect of brand knowledge on consumer response to the marketing of the brand. It is now widely acknowledged by organizations that strong brand image will create a competitive advantage in the marketplace that will enhance their overall reputation and credibility. Indeed, recent trends in modern marketing have changed enormously, and study of antecedents of brand image is increasingly becoming significant to keep pace with this change. A brand is said to have positive (negative) brand image when consumers react more (less) favorably to the antecedents of brand image for the brand. In this conceptual paper, we have summarized the literatures on currently prevailing concepts and approaches on brands that will allow us to identify the antecedents of brand image, and therefore will help organizations to enhance their marketing efficiency. Based on a comprehensive review of several earlier works, here we propose a plausible framework for the antecedents of brand image in sequential order, namely, awareness of the brand, association of the brand, superiority of the brand, affection of the brand, resonance of the brand and corporate social responsibility. In this review, we put forward the notion that the antecedents of brand image attempt need to be associated with organizational processes which will conceptualize according to an associative network of memory model through organizational activities. We suggest that these activities could play a significant role in creating brand image among consumers.
\end{abstract}

Keywords: brand image, awareness of the brand, association of the brand, superiority of the brand, affection of the brand, resonance of the brand, Corporate Social Responsibility (CSR)

\section{Introduction}

Organizations are recurrently interested in building strong brands with positive image. So much attention has been devoted recently to the concept of brand image (Park, 2009). The antecedents of brand image creates significant results that assist organizations to build strong brands which include greater consumer satisfaction, reduced price sensitivity and fewer consumer defections (Knapp, 2000). Consumers value their relationships with their branded ownerships and with marketing agents that own and control the brand (McAlexander et al., 2002). In this perspective, the brand image focuses on points of differentiation and points of identification that propose sustainable competitive advantage to the organization through the antecedents into modern marketing environment. Brand image, an imperative building block in consumer-based brand equity, is destined as "perceptions about a brand which reflected by the brand associations apprehended in consumer's memory" (Keller, 1998). Even though the term or notion brand image has been largely defined and used in diverse ways, one common agreement of the definition is that brand image is a consumer's aggregate impression of a particular brand care of the influence of a consumer's reasoned or emotional perceptions (Dobni \& Zinkhan, 1990; Aaker, 1996). Strong antecedents of brand image take pleasure in consumer loyalty, the possibility to charge premium prices, and extensive brand power to hold up new product and service launches.

In this context, this paper presents a conceptual model in the form of AASARC (Awareness, Association, Superiority, Affection, Resonance and Corporate Social Responsibility) model for building brand image that is based on a comprehensive review of the existing literatures and a case study of very prominent hotel brand in Bangladesh. An attempt has been made in the discussion section to discuss the managerial implications of the concepts presented in this paper. 


\section{Establishing Brand Image}

Brand image is formed through the amalgamated effect of brand associations; (Biel, 1991; Dobni \& Zinkhan, 1990; Yoo et al., 2000; Keller, 1998 \& 2003) As a result, brand association is considered an essential factor in abundant brand image studies. Brand association is frequently based on the associative network model (Farquhar and Herr, 1993), in which a person's memory is made up of relations and nodes: relations personify relationships (positive or negative, weak or strong), and nodes signify concepts or notions (e.g. brand associations) and objects (e.g. brands). Aaker (1991) underlies to brand associations like the category of brand's assets and liabilities that embrace anything connected with memory to a brand. Correspondingly, Keller (2003) defines brand association like informational nodes allied toward the brand node in memory that cleaves to the meaning of the brand for consumers.

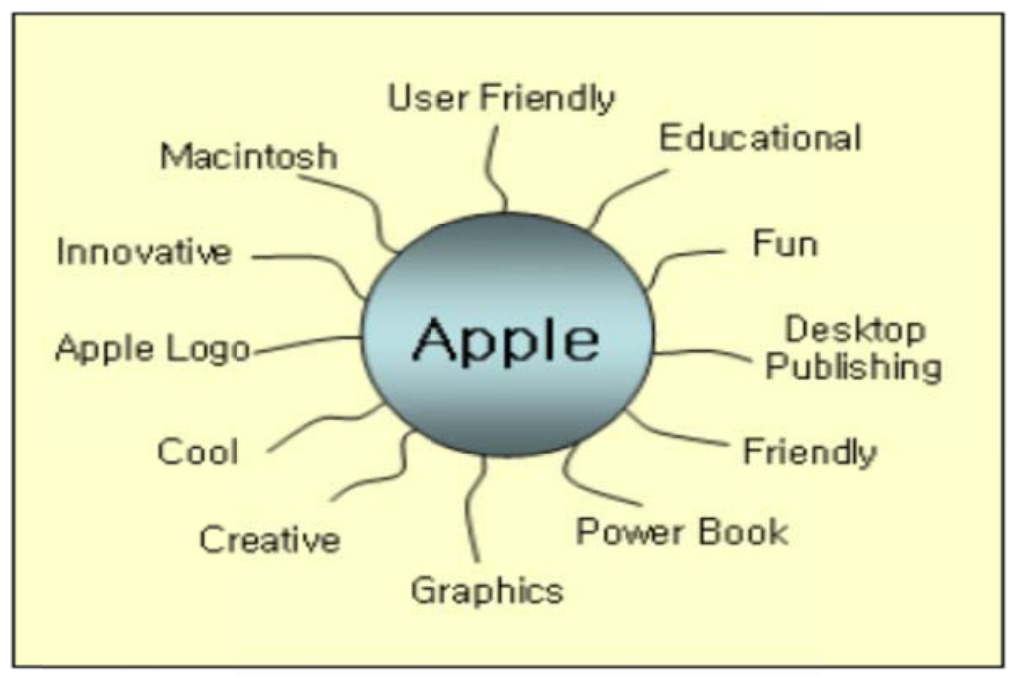

Figure 1. Brand associations (adapted from Keller, 2003)

Above figure 1 displays an example of brand associations of Apple, a most popular as well as accepted computer brand all over the world. Associations come in all appearances and may possibly reflect features of the product or facets independent of the product itself (Keller, 2003). There are three dimensions of brand associations which include strength, favorability, and uniqueness that reflect as well as are a sign of brand image (Keller, 1998).

According to Keller (1998), brand associations have been aligned into three divisions: (a) Attributes (product-related attributes such as ingredients and characteristics and non-product-related attributes such as price, user imagery, usage imagery, feelings, experiences and personality) (b) Benefits as well as advantages (functional benefits for example healthy or nutritious and symbolic advantages such as fashion ability and prestige) and (c) Attitude as well as perception that may be influenced by perception (overall evaluations). He squabbles that a positive brand image is created by marketing programs that linkage strong, favorable, and unique associations to the brand in memory. Associations that are the strongest, most favorable, and unique are nearly all legally responsible to be activated and contribute to the brand image (Keller, 2003).

For that reason, brand image is encompassed brand loyalty which goal is to build strong relationships with consumers in that case not only build strong relationship but also maintain relationship for a long period of time that is called Customer Relationship Management (CRM). As a result, brand image makes imperative action to investigate the effect of antecedents including brand awareness, brand association, brand superiority, brand affection, brand resonance and corporate social responsibility.

\section{AASARC Model: A Conceptual Model for the Antecedents of Brand Image}

Based on the literature review, the conceptual model for the antecedents of brand image in a competitive market, known as AASARC Model, has been proposed. The six elements of this model, namely, awareness of the brand, association of the brand, superiority of the brand, affection of the brand, resonance of the brand and corporate social responsibility of the brand are discussed below. 


\subsection{Awareness of the Brand}

Brand awareness, according to Keller (2008), that holds brand recognition and brand recall performance. In cooperation, both are important components in sustaining brand equity whose main aim to achieve a strong brand image with long term relationship that indicate brand loyalty. Brand recognition is defined as the consumers' ability to authenticate earlier revelation to the brand when given the brand as an indication while brand recall is consumers' ability to recoup the brand from memory when given the product category, the needs satisfied by the category, or a purchase or habit situation as a reminder (Keller, 2008). Aaker (1991) advocates that brand awareness engage a continuum ranging from an undecided feeling that the brand is recognized, to a faith that it is the barely one in the product class. Even though the last decades' particular literature exposed and crystallized the thought of brand equity (in relative to which brand awareness is one of the primary dimensions) the term has been and at a standstill is approached in numerous manners in the specialized literature.

Moreover, brand awareness has a direct pressure on brand image in that it is the first step in building strong, positive associations in the mind of the consumer. Campbell and Keller (2003) demonstrated the significance of brand familiarity in their examination of advertising reiteration. They bring into being that a well-known, recognizable brand would not undergo from advertising "burnout" from overexposure in the media. Comparatively unfamiliar brands were found to suffer from advertising incompetence and flat to "burnout" as a result of this unfamiliarity. So brand awareness make a connectivity that convert unfamiliarity to familiarity of a brand. From a consumer brand awareness perspective, marketers must be able to understand as well as create brand image where awareness of the brand act as an antecedent.

\subsection{Association of the Brand}

Brand associations are tremendously helpful to marketers. Marketers make use of brand associations to differentiate, position, and extend brands, to build and create positive attitudes and feelings towards brands, and to recommend attributes or benefits of purchasing or using a particular brand (Aaker, 1991). Brand associations, on the other hand, are of more use to the customer than the marketer. The approach as well as the way a brand association creates value to the customer will depend on the customer's perception of value. In support of each individual, reality is a completely personal observable fact, based on that person's needs, wants, and personal experiences.

Keller (1993) marked brand as "a set of associations associated with the brand that consumers embrace in memory" (p. 3). A brand image is cool, calm and collected of a set of associations regarding the brand in the mind of the consumer. Brand associations are considered to be the informational nodes connected to a brand node that includes the meaning of the brand in the mind of the consumer (Keller, 1998). In the same way, brand associations are considered any idea associated with the brand in the mind of the consumer (Aaker, 1991). Marketers use brand associations for product positioning reasons whereas consumers use brand associations to help guide their decision making (Low \& Lamb, 2000). As a result, association of the brand is a one of the key antecedent of brand image for a building strong brand.

\subsection{Superiority of the Brand}

Brand superiority and brand attitudes are extremely correlated each other and generate in that while they both communicate and interact with the consumer's aggregate cognitive evaluation of a target brand. The major difference lies in the conflicting operationalization of each construct or builds from a measurement point of view. Brand attitudes are first and foremost measured using a semantic differential scale attached through contrasting adjectives. Brand superiority measures the consumer's aggregate and collective cognitive evaluation of the brand in next of kin to competing brands. The brand superiority arrests the uniqueness and differentiation that consumers perceive when they judge a brand in relation to its competitors. In this regard, this measure is challenging to confine one of the definitive goals or aims of successful branding: the construction as well as the formation of a brand that is unique or distinctive from its rivals.

Consumers compose a multitude of evaluations with esteem to a definite brand although they commonly form their attitudes about a brand based on attributes and benefits provided by the brand (Keller, 2003). In addition, perceptions as regards the attributes and benefits of a brand are formed based on the marketing communication in respect of the brand, word-of-mouth from other consumers, and direct experiences with the brand. Brand attributes can be separated into product-related and non-product related categories. Product-related attributes underline to the functional attributes for example technological and functional distinctiveness of the product that are compulsory for its functioning. In most circumstances, a widespread attitudinal target of a brand is the perceived quality or superiority of the brand in contrast to the competition. Non-product related attributes underline to outside attributes of the product for example price, product appearance, user imagery, and usage 
information. The two most important appearances of non-product attributes that consumers evaluate and form attitudes about being priced and brand imagery. Price has been shown to persuade consumer perceptions of the brand. Yoo et al., (2000) uncovered that the price and continuation of price promotions impact the quality perception of the brand on the mind of the consumer. Brands that employed price promotions as well as set their price lower than the competition were uncovered to have a lower level of perceived quality by consumers. Brand imagery focuses a wide non-product attribute that consumers base their evaluations above. There are many appearances of a brand's image that can be appraised by consumers. Thus superiority of the brand is one of the key antecedents of brand image which assist to create a strong brand for organizations.

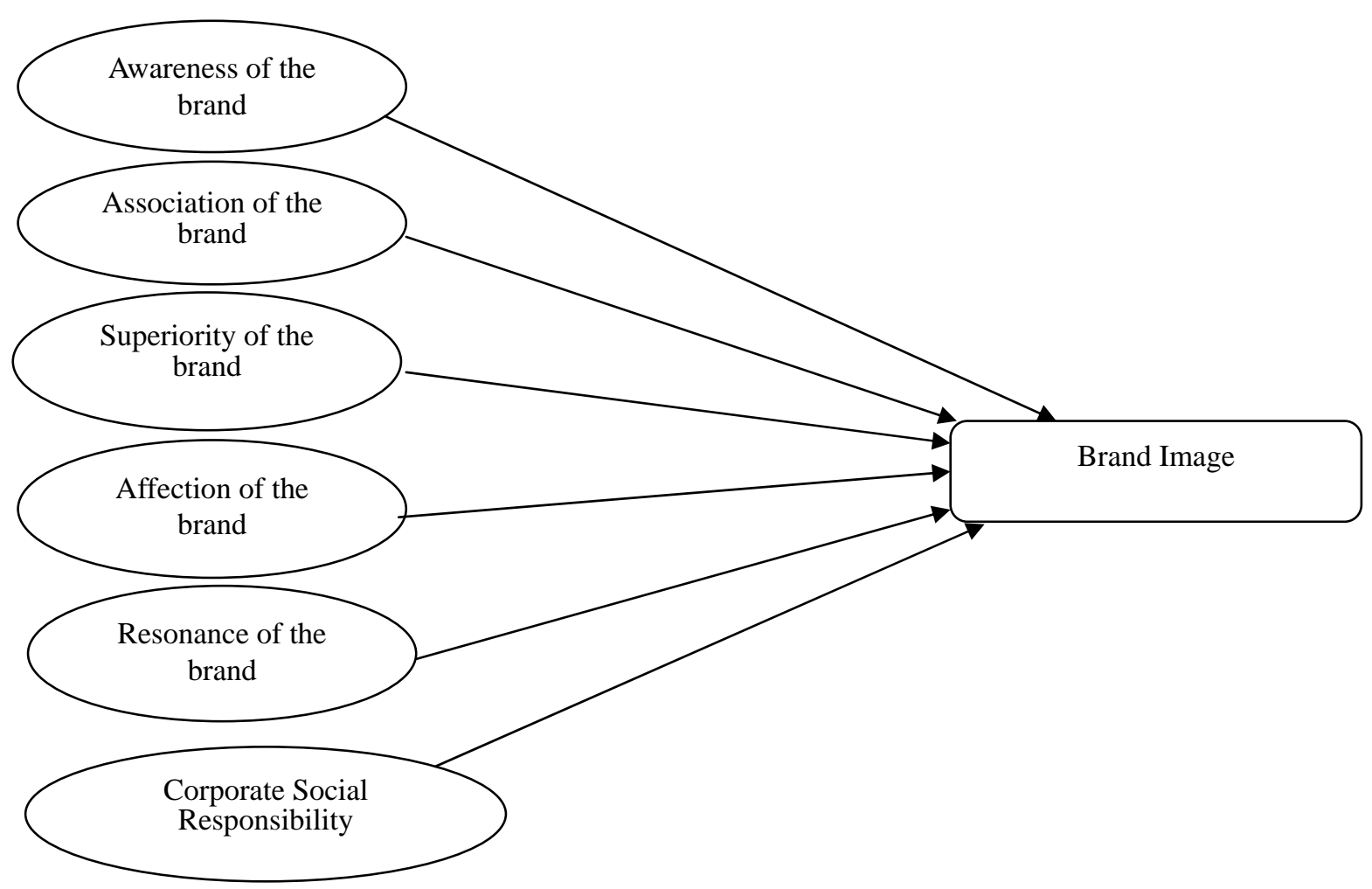

Figure 2. AASARC conceptual model

\subsection{Affection of the Brand}

In the context of affection, emotions play an important role in consumer reaction and engage a vital position in consumer behavior (Bagozzi et al., 1999; Chaudhuri \& Holbrook, 2001; Richins, 1997). In a modern consumer attitude model, emotional responses arbitrated the relationship between cognitive appraisals and behavioral intentions to a prearranged stimulus that proposed by Bagozzi (1992). The degree to which a brand is competent to emotionally relate to consumers will increase the likeliness that they will keep consumers and positively impact the perceptions of the brand in the mind of the consumer. Therefore, considering brand affect the consumer-based brand equity that is confirmed by Keller (2001 \& 2003) should focus attributes, identity and orientation. These are illustrated below:

First, brand attributes- which emphasis the functional or emotional associations that are allocated to a brand by its consumers and prospects. Brand attributes can be either negative or positive and can have varying degrees of consequence and significance to different customer segments. Brand attributes are the key in maintaining brand loyalty that ultimate goal is to increase brand image.

Second, brand identity- which underlies an identical product, service, person or place, augmented in such a wherewithal that the buyer or user perceives pertinent, unique added values which match their needs most narrowly that collected by Chernatony and McDonald (1998). In different words, the identity of the brand matches consumer needs that focus on points of differentiation which offer sustainable competitive advantage to the organization and assist to build brand image (Ghodeswar, 2008). 
Third, brand orientation- according to Wong and Merrilees (2008), underlies to a conscious, purposeful approach to working with brands, both inwardly and faraway. This approach is characterized by the brand serving kind of a hub around which an organization's strategic processes circle.

More significantly, brand affection has been increased market share and enhance brand image for an organization. For which affection of the brand can play a major antecedent that aim to increase brand image.

\subsection{Resonance of the Brand}

Brand resonance indicates to the final relationship that consumers apprehend told a brand as well as the spread to which the consumer feels "in sync" with a certain or specific brand (Keller, 2003). With appropriate brand resonance, consumers coherent a high degree of loyalty to the brand like that they enthusiastically quest means to intermingle with the brand and allocate their experiences with others. Organizations that are able to ascertain brand resonance should produce a host of benefits or values, for instance, greater price premiums and more efficient and effective marketing programs (Keller, 2003). Fundamentally brand resonance is the eventual as well as final relationship between a brand and a consumer where loyalty can play active role (Keller, 2002). The level of relationship that a consumer has together with a brand can be acknowledged through the amount of action the consumer engages and practices in unto the brand as well as the strength of the relationship the consumer has together with various users of the brand. A consumer that uses the brand frequently or connects with various activities aimed at the brand is acknowledged as having a high action and activity level with the brand. Even, a consumer that endlessly connects and communicates with various consumers of the brand, participating brand stories, and aiding in the use of the brand is acknowledged as having a high level of greatness on the part of the brand.

Moreover, pointed out product or service categories potentially permit for more resonance forasmuch as they have intrinsically high levels of interest and activities. Brand resonance expresses how to build strong and active loyal relationships with consumers and for which that increase and enhance brand image for an organization and also anchor as antecedent of brand image (Keller, 2007, 2008 \& 2009). Indeed, resonance of the brand is an antecedent that assists marketers to create brand image and build organizational reputation.

\subsection{Corporate Social Responsibility (CSR)}

More organizations today are beginning to understand the significance of Corporate Social Responsibility (CSR), and its impact on societal well being, aside from the aggregate supremacy of the supply chain processes of every organization (Murali Raman et al., 2012). In the past, financial performance was the main principle to evaluate a firm's value. Higher ranks were given to firms that offer greater margins economically. Maximization of shareholders' wealth was, until, the central point of profit-driven organizations. In this consideration, the stress on CSR in the past was not apparent. In this decade, on the other hand, the perception about CSR has changed considerably (Asaad, 2010). At the present the success of an organization is also being measured by its contribution to society (Pokorny, 1995; Saunders, 2006). Individualistic and unprincipled behavior in business can be prevented by Corporate Social Responsibility (CSR) (Pakseresht, 2010).

To win brand resonance in today's markets, organizations have to focus on building and maintaining consumer loyalty and CSR has become a useful tool in this consideration that end result is to increase brand image as well as continuously connect with CSR practices for sustaining brand image and brand resonance for which consumers' reaction positively keep to brand for long period of time. CSR might affect the value of an organization's brand and its brand performance. Strong competition has in many markets decreased the prospects for differentiation and uniqueness in terms of technology and product/service quality that why we considering the nature of competition and make strategies based on pattern of competition to increase prospects by using differentiation and uniqueness. For this reason and circumstance, CSR is an essential antecedent that can improve an organization's image as well as brand image. Thus, most organizations consider CSR to be a key antecedent and take competitive advantage for building brand image in the modern marketing environment.

\section{Case Study}

Case study of one Bangladeshi brand of hotel was undertaken to delineate the approach for building brand image adopted by one brand of hotel at Bangladesh. The action points suggested through case study reinforced the proposed AASARC model for building brand image where all components of suggested model play as antecedents for brand image of brands of hotels.

\subsection{ABC Residence Hotel}

ABC Residence, the truly, international standard, boutique style, small, luxury hotel in capital city Dhaka at Bangladesh, which has a very high degree of personalized service is owned and managed by a Sri Lanka based 
BOI company in Dhaka. ABC is the only hotel in Bangladesh to be certified with ISO 2000 and HACCP. ABC started their activities from January-2000 and since then it has been running with good reputation as well as consumer satisfaction. At starting it was managed by Confifi hotel Chain and now it is operated by owner STS Group. The STS Group also running several business enterprises including Apollo Hospital Dhaka, ISD School, DPS School, Shanta Garments, LonkaBangla Finance etc. ABC is conveniently located beside airport road as well as the diplomatic zone at Banani leading to the main city, and adjacent to the diplomatic enclave and upcoming blue chip commercial hub of Baridhara, Gulshan \& Banani, only $7 \mathrm{~km}$ from the main international airport. The hotel is comprising 66 rooms and suites including all rooms feature king, queen or twin size beds, large work areas with High-Speed Internet, direct control air-conditioning, in-room safe, mini bar, tea/coffee making facilities and ironing facilities. ABC Residence is doing regular sales visit to the different organizations (RMG, FMCG, MEDIA, MEDICAL COLLEGE, HOSPITALS, NGO, different AID organizations such as UNAID, German AID, USAID etc.). The hotel management maintaining a very good relation with the media sectors especially the print media. They are using the integrated marketing tools in their marketing strategy and business expansion. They distribute Eid festival Greetings Card, New Year and Christmas Greetings Card. They also distribute their special Cake \& gift hampers to their most valuable and big clients time to time (ABC Residence Hotel, available at http:// www.royalparkbd.com). ABC Residence provides different services for the consumers. In general, inside each room they provide air condition, DVD player, television with cable, mini bar, free newspaper, hairdryer, outlet adapters, turndown service, iron with ironing board, smoke detectors and sprinklers in rooms. As room service, they also provide elevators, executive level corridor, ice machine, 24 hour security, phone service etc. Outside the rooms they provide outdoor pool, fitness center, gym, Jacuzzi, Sauna, Steam bath, business center, laundry service, shoe polishing service, concierge desk, wake-up service, meeting/banquet facilities, car rental desk, boutiques, conference facilities, currency exchange, outside catering, accessible facilities for wheel chair access etc. Overall, the ABC Residence is a three star and international standard boutique hotel. The main concept of boutique hotel is personalized service. In this regard, the hotel is providing their best support to make their consumers happy and satisfied. For example, if one consumer wants to eat less spicy food their kitchen people make a note and try to make the food according the consumer choice. The location of ABC is in a good diplomatic area and the environment is very calm and quiet. The hotel cost is reasonable according to the services. The hotel also does outside catering which is one of their specialties. Adding another feather in their cap, ABC was awarded with the "Certificate of Excellence" for year 2013 by Trip Advisor. This prestigious award, which places organizations in the top-performing $10 \%$ of all businesses worldwide on Trip Advisor, is given to businesses that consistently earn high ratings from Trip Advisor travelers. Couple of months ago, Trip Advisor placed ABC, the best hotel in terms of guest reviews in Bangladesh and now has been recognized amongst the best globally, which amply proves beyond doubt $\mathrm{ABC}$ has earned the top slot amongst the best in the world from its own patrons (ABC Residence Hotel, available at http:// www.royalparkbd.com). In fact, consumers are fall in love to ABC because they maintain a good relationship between their hotel customers and their patrons those are providing or try to provide the link that assist their business operations. They are highly concern about customer satisfaction. They maintain a customer comments sheet and if any complaint is there they will try to remove with top priority basis. $\mathrm{ABC}$ has suggestion box where customers as well as employees can drop their suggestions with written format. After a time being ABC will organize corporate dinner party, cocktails party, BBQ party where most of the hosts are invited from different organizations. ABC practices good relations with diplomats, Embassy and High Commission. Moreover, ABC tries to provide extra services which are out of customer's expectation. For example, one customer he or she is staying with them for five days during that time his/her birthday may be occurred. Suddenly they will arrange a surprise birthday party only honor of his or her honorary. Furthermore, ABC has adapted corporate social responsibility as a part of their mission. They have made corporate social responsibility one of the important principles of their business. In the context of corporate social responsibility, ABC provides good food like Chicken Briany every Saturday of a week for 150 persons to missionary of charity at Islampur. They also provide Chicken Briany every $18^{\text {th }}$ day for 175 persons, $20^{\text {th }}$ day for 100 persons, $27^{\text {th }}$ day for 100 persons and $31^{\text {st }}$ day for 100 persons of a month at different places those are Botomoly orphanage at Farmget, missionary of charity at Tejgaon, Jagoroni Jute Holicross at Tejgaon, road side people at several areas of Dhaka city and Ashkona orphanage centre (ABC Residence Hotel, available at http:// www.royalparkbd.com). The following table represents the antecedents of brand image building of ABC Residence Hotel. 
Table 1. The antecedents of brand image building

\begin{tabular}{|c|c|}
\hline \multicolumn{2}{|r|}{ Brand Image } \\
\hline Antecedents & ABC Residence Hotel \\
\hline Awareness & $\begin{array}{l}\text { ABC Residence is doing regular sales visit to the different organizations (RMG, FMCG, } \\
\text { MEDIA, MEDICAL COLLEGE, HOSPITALS, NGO, different AID organizations such as } \\
\text { UNAID, German AID, USAID etc.). }\end{array}$ \\
\hline Association & $\begin{array}{l}\text { ABC Residence provides different services for consumers. In general, inside the rooms they } \\
\text { provide air condition, DVD player, television with cable, mini bar, free newspaper, } \\
\text { hairdryer, outlet adapters, turndown service, iron with ironing board, smoke detectors, } \\
\text { sprinklers, elevators, executive level corridor, ice machine, } 24 \text { hour security, phone service } \\
\text { etc. Outside the rooms they provide outdoor pool, fitness center, gym, Jacuzzi, Sauna, } \\
\text { steam bath, business center, laundry service, shoe polishing service, concierge desk, } \\
\text { wake-up service, multilingual, meeting/banquet facilities, car rental desk, boutiques, } \\
\text { conference facilities etc. In dinning, they provide several buffet menus. }\end{array}$ \\
\hline Superiority & $\begin{array}{l}\text { ABC is a three star and international standard boutique hotel. The main concept of boutique } \\
\text { hotel is personalized services. They are providing their best support to make their } \\
\text { consumers happy and satisfied. For example, if one consumer wants to eat less spicy food } \\
\text { their kitchen people make a note and try to make a food according a consumer choice. The } \\
\text { location of ABC is in a good diplomatic area and the environment is very calm and quiet. } \\
\text { The hotel cost is reasonable according to the services. They also do outside catering which } \\
\text { is one of their specialties. Adding another feather in their cap, ABC was awarded with the } \\
\text { "Certificate of Excellence" for year } 2013 \text { by Trip Advisor. }\end{array}$ \\
\hline Affection & $\begin{array}{l}\text { In fact, consumers are fall in love to ABC because they are highly concern about customer } \\
\text { satisfaction. They maintain a customer comments sheet and if any complaint is there, they } \\
\text { will try to remove with top priority basis. ABC tries to provide extra services which are out } \\
\text { of customer's expectation. For example, one customer he or she is staying with them for } \\
\text { five days during that time his/her birthday may be occurred. Suddenly they will arrange a } \\
\text { surprise birthday party only honor of his or her honorary. }\end{array}$ \\
\hline Resonance & $\begin{array}{l}\text { ABC practices good relations with diplomats, Embassy and High Commission. They } \\
\text { maintain a good relationship between their hotel customers and their patrons those are } \\
\text { providing or try to provide the link that assist their business operations. ABC have } \\
\text { suggestion box where customers as well as employees can drop their suggestions with } \\
\text { written format. After a time being ABC will organize corporate dinner party, cocktails } \\
\text { party, BBQ party where most of the hosts are invited from different organizations. }\end{array}$ \\
\hline $\begin{array}{c}\text { Corporate Social } \\
\text { Responsibility }\end{array}$ & $\begin{array}{l}\text { ABC has adapted corporate social responsibility as a part of their mission. In the context of } \\
\text { corporate social responsibility, ABC provides Chicken Briany every } 18^{\text {th }} \text { day for } 175 \\
\text { persons, } 20^{\text {th }} \text { day for } 100 \text { persons, } 27^{\text {th }} \text { day for } 100 \text { persons and } 31^{\text {st }} \text { day for } 100 \text { persons of a } \\
\text { month at different places those are Botomoly orphanage at Farmget, missionary of charity } \\
\text { at Tejgaon, Jagoroni Jute Holicross at Tejgaon and road side people at several areas of } \\
\text { Dhaka city. }\end{array}$ \\
\hline
\end{tabular}




\section{Discussion}

The suggested AASARC model can serve as a guideline to managers and executives in building image of their brands in their target markets through constructing the anticipated antecedents of brand image. As competition gets more concentrated, managers face challenges to curvature their brands and accelerate their brand image with changed expectations of their consumers. Among different alternatives that are available to the managers, conscious their brands and brand image based on the antecedents' performance that happen to be the consumer wealth can assist in building image of their brands in the minds of their consumers. Basically the antecedents of brand image can enable organizations to leverage current resources to the extent possible and change in total impression of the brand and its organization. The success of brand marketing should be based on a systematic analysis of customer impressions of a brand, perceptions of a brand (brand image), and their reliance or dependence (brand trust) on a specific brand, which have an effect on brand familiarity, customer satisfaction and loyalty (attitudinal brand loyalty) where this suggested AASARC model can play a vital role. With the help of suggested AASARC model managers can easily build strong brand image of their organizations into the modern marketing environment and able to face strong competition by taking such kind of competitive advantage into the target market. This proposed conceptual model may assists managers and brand executives in understanding as well as evaluation of brand image. The proposed model will be useful to better assess brand awareness, brand association, brand superiority, brand affection, brand resonance and corporate social responsibility to achieve and accomplish favorable brand image into the today's modern marketing environment.

Every organization needs to position their brands in the minds of consumers. In this regard, the suggested AASARC model will reveal how customers perceive the image of brands. Thus, this model may assist managers to understand customer's evaluation of their brand and help them in developing clear directions to position their brands based on customer preferences. Additionally, an examination and implementation of the effects of antecedents of the brand image will advance and move ahead marketer understands of factors that may improve or enhance brand strength and provide valuable insights into brand equity management. On the basis of proposed model, the brand managers and executive managers need to eternally track their brands in opposition to the effect of competition and to track the improvement as well as development as to how their brands are doing in the marketplace.

Monitoring the improvement of brands in terms of purchasing, consumption, brand recognition, brand recall, brand position, etc. assists the managers to adjust their strategies of marketing to accomplish the desired performance of their brands which easily conducting by AASARC model. This performance audit on the basis of proposed model can also facilitate the organization to measure its brand strength vis-à-vis competing brands in a competitive market. Constructing this proposed AASARC model, an organization can reduce the vulnerability of the consumer base to long term relationship action that indicate and specify constant purchase as well as positive worth of mouth and can straightly interpret or construe into future sales and profits. Brands that have established desired brand resonance in the marketplace can have strong loyalty through this proposed model. These approaches allow the organizations to influence the antecedents of brand image to new categories of uniqueness as well as differentiation that hold on superiority and plan a new intensification path for their brands for achieving brand image through this suggested AASARC model.

To build a strong brand, the right brand knowledge structures must exist in the minds of actual or prospective customers so that they respond and take action positively to marketing activities and programs. In this standpoint, AASARC model can play a crucial role in shaping and assisting brand knowledge. This proposed model can contribute to brand equity by establishing the brand in memory and creating a brand image. For this reason, considering this suggested model managers can get competitive advantage from competitive market. Due to this proposed model, managers easily take decision and set strategies for their organizational programs.Furthermore, this proposed model provides a great understanding of the importance of brand image in retaining brand loyalty. Loyal customers are less likely to change to a rival's brand and are more likely to make more frequent and regular purchases than comparable non-loyal customers. Thus, it is significant for organizations as well as brand managers to realize the importance of brand image in the customer-based brand equity and realize the need to expose their organizational performance to as many customers as possible due to build and enhance the customer's brand loyalty.

Finally, this proposed model will not only provide theoretical confirmation that supports the significance of brand image but also present an implementation process which shows how the image of brands can impact of organization's market performance into the marketplace. Thus, this proposed model provides the much needed evidence that high level of brand awareness, brand association, brand superiority, brand affection, brand resonance and corporate social responsibility increase the probability of brand image. 


\section{Conclusion}

This paper discusses the AASARC model for building brand image and is based on the review of pertinent literatures with a case study. For the purpose of this paper, the antecedents of brand image were considered a multidimensional construct that create a competitive advantage in the marketplace and enhance organizational overall reputation, status and credibility. Hence, the antecedents of brand image dimensions in the context of suggested AASARC model would be a potential for building a strong brand into marketplace in the modern marketing environment because the antecedents of brand image with dimensionality can offer a variety of valuable managerial implications that brand managers can benefit from. Although many of the ideas articulated in this proposed conceptual model may be recognizable to managers, its value is in integrating these different notions to provide a more inclusive picture of how organizations can create value and sustain value for a brand. But the matter of fact by recognizing this proposed conceptual model organizations will take better shot-term and long-term marketing actions into a competitive marketplace. Therefore, The six stages suggested in AASARC model namely, awareness of the brand, association of the brand, superiority of the brand, affection of the brand, resonance of the brand and corporate social responsibility of the brand can enable organizations to build strong brand image as well as strong brands in a competitive market.

\section{References}

Aaker, D. A. (1991). Managing Brand Equity. Ontario: The Free Press.

Aaker, D. A. (1996). Building strong brands. New York: The Free Press.

ABC. (n. d.). ABC Residence Hotel. Retrieved January 31, 2014, from http://www.royalparkbd.com

Asaad, A. (2010). The role of brand equity in the effects of corporate social responsibility on consumer loyalty (Unpublished master's dissertation). Universiti Sains Malaysia, Malaysia.

Bagozzi, R. P. (1992). The self-regulation of attitudes, intentions, and behaviours. Social Psychology Quarterly, 55, 178-184. http://dx.doi.org/10.2307/2786945

Bagozzi, R. P., Gopinath, M., \& Nyer, P. U. (1999). The role of emotions in marketing. Journal of the Academy of Marketing Science, 27(2), 184-206. http://dx.doi.org/10.1177/0092070399272005

Biel, A. L. (1991). The brandscape: converting brand image into equity. Admap, 26(10), 41-46.

Campbell, M. C., \& Keller, K. L. (2003). Brand familiarity and advertising repetition effects. Journal of Consumer Research, 30(September), 292- 304. http://dx.doi.org/10.1086/376800

Chaudhuri, A., \& Holbrook, M. B. (2001). The chain of effects from brand trust \& brand affect to brand performance: The role of brand loyalty. Journal of Marketing, 65(2), 81-93. http://dx.doi.org/10.1509/jmkg. 65.2.81.18255

Chernatony, L., \& McDonald, M. (1998). Creating Powerful Brands (2nd ed.). Butterworth- Heinemann, Oxford.

Dobni, D., \& Zinkhan, G. M. (1990). In search of brand image: A foundation analysis. Advances in Consumer Research, 17(1), 110-119.

Farquhar, P. H., \& Herr, P. M. (1993). The dual structure of brand associations. Brand equity and advertising: Advertising's role in building strong brands, 263-277.

Ghodeswar, B. M. (2008). Building brand identity in competitive markets: A conceptual model. Journal of Product \& Brand Management, 17(1), 4-12. http://dx.doi.org/10.1108/10610420810856468

Keller, K. L. (1993). Conceptualizing, measuring and managing customer based brand equity. Journal of Marketing, 57(1), 1-22. http://dx.doi.org/10.2307/1252054

Keller, K. L. (1998). Strategic Brand Management: Building, Measuring, and Managing Brand Equity. Upper Saddle River, NJ: Prentice Hall.

Keller, K. L. (2001a). Building customer-based brand equity: A blueprint for creating strong brands (pp. 68-72). Marketing Science Institute.

Keller, K. L. (2001b). Building customer-based brand equity. Marketing Management, 10(2), 14-21.

Keller, K. L. (2002), Strategic brand management; building, measuring and managing brand equity. Prentice Hall, Upper Saddle River, N. J.

Keller, K. L. (2003a). Brand synthesis: The multidimensionality of brand knowledge. Journal of consumer 
research, 29(4), 595-600. http://dx.doi.org/10.1086/346254

Keller, K. L. (2003b). Strategic brand management: Building, measuring, and managing brand Equity (2nd ed.). Boston, MA: Pearson Education.

Keller, K. L. (2007). Advertising and brand equity. GJ Tellis, \& T. Ambler, Handbook of Advertising, 54-70.

Keller, K. L. (2008). Strategic brand management: Building, measuring, and managing brand equity (3rd ed.). New Jersey, N.J.: Prentice-Hall.

Keller, K. L. (2009). Building strong brands in a modern marketing communications environment. Journal of Marketing Communications, 15(2-3), 139-155. http://dx.doi.org/10.1080/13527260902757530

Knapp, D. E. (2000). The Brand Mindset (pp. 33, 36 \& 103). New York: McGraw-Hill.

Low, G. S., \& Lamb, C. W. (2000). The measurement and dimensionality of brand associations. Journal of Product and Brand Management, 9(6), 350-370. http://dx.doi.org/10.1108/10610420010356966

McAlexander, J. H., Schouten, J. W., \& Koenig, H. F. (2002). Building Brand Community. Journal of Marketing, 66(1), 38-54. http://dx.doi.org/10.1509/jmkg.66.1.38.18451

Pakseresht, A. (2010). Brand equity and corporate responsibility: A review of brand valuation methods. Retrieved January 20, 2014, from http://www.essays.se/essay/9e20739689/

Park, S. H. (2009). The antecedents and consequences of brand image: Based on Keller's customer-based brand equity (Doctoral dissertation, The Ohio State University).

Pokorny, G. (1995). Building brand equity and customer loyalty. Retrieved January 23, 2014, from http://findarticles.com/p/articles/mi_qa3650/is_199505/ai_n8728762/pg_3/?tag=content;col1

Raman, M., Lim, W., \& Nair, S. (2012). The Impact of Corporate Social Responsibility on Consumer Loyalty. Journal of Malaysian Studies, 30(2), 71-93.

Richins, M. L. (1997). Measuring emotions in the consumption experience. Journal of Consumer Research, 24(2), 127-146. http://dx.doi.org/10.1086/209499

Saunders, R. (2006). CSR: How to get an ethical advantage. Retrieved January 3, 2014, http://www.highbeam.com/doc/1G1-156029766.html

Wong, H. Y., \& Merrilees, B. (2008). The performance benefits of being brand-orientated. Journal of Product and Brand Management, 17(6), 372-383. http://dx.doi.org/10.1108/10610420810904112

Yoo, B., Donthu, N., \& Lee, S. (2000). An examination of selected marketing mix elements and brand equity. Journal of the Academy of Marketing Science, 28(2), 195-211. http://dx.doi.org/10.1177/00920703002 82002

\section{Copyrights}

Copyright for this article is retained by the author(s), with first publication rights granted to the journal.

This is an open-access article distributed under the terms and conditions of the Creative Commons Attribution license (http://creativecommons.org/licenses/by/3.0/). 